\title{
Idiomarina salinarum sp. nov., isolated from a marine solar saltern in Korea
}

\author{
Jung-Hoon Yoon, Seo-Youn Jung, Yong-Taek Jung and Tae-Kwang Oh \\ Korea Research Institute of Bioscience and Biotechnology (KRIBB), PO Box 115, Yusong, \\ Taejon, Korea
}

Correspondence

Jung-Hoon Yoon

jhyoon@kribb.re.kr

\begin{abstract}
A Gram-negative, motile, rod-shaped, Idiomarina-like bacterial strain, ISL-52 ${ }^{\top}$, was isolated from a marine solar saltern of the Yellow Sea in Korea and was subjected to a polyphasic taxonomic investigation. Strain ISL-52 ${ }^{\top}$ grew optimally at $\mathrm{pH} 7.0-8.0$ and at $30-37^{\circ} \mathrm{C}$. It contained Q-8 as the predominant ubiquinone. The major fatty acids ( $>10 \%$ of total fatty acids) were iso- $\mathrm{C}_{15: 0 \text {, }}$ iso- $\mathrm{C}_{17: 0}$ and iso- $\mathrm{C}_{17: 1} \omega 9 \mathrm{c}$. The DNA G+C content was $53.9 \mathrm{~mol} \%$. A phylogenetic analysis based on 16S rRNA gene sequences showed that strain $I S L-52^{\top}$ fell within the genus Idiomarina, joining the type strain of Idiomarina homiensis at a bootstrap resampling value of $100 \%$. Strain ISL-52 ${ }^{\top}$ exhibited $16 \mathrm{~S}$ rRNA gene sequence similarity values of $94.9-96.7 \%$ with respect to the type strains of eight recognized /diomarina species. The differential phenotypic properties of ISL $-52^{\top}$, together with its phylogenetic distinctiveness, demonstrated that this strain is distinguishable from the recognized Idiomarina species. On the basis of phenotypic, phylogenetic and genetic data, therefore, strain ISL $-52^{\top}$ represents a novel species of the genus Idiomarina, for which the name Idiomarina salinarum sp. nov. is proposed. The type strain is ISL-52 ${ }^{\top}\left(=\right.$ KCTC $12971^{\top}=$ CCUG $\left.54359^{\top}\right)$.
\end{abstract}

The genus Idiomarina was created by Ivanova et al. (2000) with the description of Idiomarina abyssalis and Idiomarina zobellii. Subsequently, six further Idiomarina species, Idiomarina baltica (Brettar et al., 2003), Idiomarina loihiensis (Donachie et al., 2003), Idiomarina fontislapidosi and Idiomarina ramblicola (Martínez-Cánovas et al., 2004), Idiomarina seosinensis (Choi \& Cho, 2005) and Idiomarina homiensis (Kwon et al., 2006), have been described. In this study, we report on the taxonomic characterization of an Idiomarina-like bacterial strain, ISL- $52^{\mathrm{T}}$, isolated from a marine solar saltern of the Yellow Sea in Korea.

Strain ISL $-52^{\mathrm{T}}$ was isolated by means of the dilution plating technique at $30{ }^{\circ} \mathrm{C}$ on marine agar 2216 (MA; Difco) supplemented with $8 \%(\mathrm{w} / \mathrm{v}) \mathrm{NaCl}$. The morphological, physiological and biochemical characteristics of strain ISL$52^{\mathrm{T}}$ were investigated using routine cultivation on MA at $37{ }^{\circ} \mathrm{C}$. The cell morphology was examined by light microscopy (E600; Nikon) and transmission electron microscopy. Flagellation was determined by using a Philips CM-20 transmission electron microscope with cells from exponentially growing cultures: for this purpose, the cells were negatively stained with $1 \%(\mathrm{w} / \mathrm{v})$ phosphotungstic acid and the grids were examined after being airdried. Growth under anaerobic conditions was determined after incubation in a Forma anaerobic chamber on MA and on MA supplemented with nitrate, both of which had been

The GenBank/EMBL/DDBJ accession number for the 16S rRNA gene sequence of strain ISL- $52^{\top}$ is EF486355. prepared anaerobically using nitrogen. The $\mathrm{pH}$ range for growth was determined in marine broth 2216 (MB; Difco) that had been adjusted to various $\mathrm{pH}$ values $(\mathrm{pH} 4.5-9.5$, using increments of $0.5 \mathrm{pH}$ units). Growth in the absence of $\mathrm{NaCl}$ was investigated using trypticase soy broth prepared according to the formula of the Difco medium except that $\mathrm{NaCl}$ was excluded. Growth at various $\mathrm{NaCl}$ concentrations was investigated in $\mathrm{MB}$ or trypticase soy broth (Difco). Growth at various temperatures $\left(4-45{ }^{\circ} \mathrm{C}\right)$ was measured on MA. Catalase and oxidase activities and hydrolysis of casein, starch and Tweens 20, 40, 60 and 80 were determined as described by Cowan \& Steel (1965). DNase activity was examined by using DNase test agar with methyl green (Difco) supplemented with $3 \%$ (w/v) $\mathrm{NaCl}$. Hydrolysis of hypoxanthine, tyrosine and xanthine was tested on MA using the substrate concentrations described by Cowan \& Steel (1965). Hydrolysis of aesculin, gelatin and urea and reduction of nitrate were investigated as described previously (Lanyi, 1987) with the modification that artificial seawater was used for preparation of the media. The artificial seawater contained the following $\left(\mathrm{l}^{-1}\right.$ distilled water): $23.6 \mathrm{~g} \mathrm{NaCl}, 0.64 \mathrm{~g} \mathrm{KCl}, 4.53 \mathrm{~g}$ $\mathrm{MgCl}_{2} \cdot 6 \mathrm{H}_{2} \mathrm{O}, \quad 5.94 \mathrm{~g} \quad \mathrm{MgSO}_{4} \cdot 7 \mathrm{H}_{2} \mathrm{O}$ and $1.3 \mathrm{~g}$ $\mathrm{CaCl}_{2} \cdot 2 \mathrm{H}_{2} \mathrm{O}$ (Bruns et al., 2001). $\mathrm{H}_{2} \mathrm{~S}$ production was tested as described previously (Bruns et al., 2001). Susceptibility to antibiotics was investigated on MA plates by using antibiotic discs with the following concentrations ( $\mu \mathrm{g}$ unless indicated otherwise): polymyxin B, $100 \mathrm{U}$; streptomycin, 50; penicillin G, 20 U; chloramphenicol, 100; 
ampicillin, 10; cephalothin, 30; gentamicin, 30; novobiocin, 5; tetracycline, 30; kanamycin, 30; lincomycin, 15; oleandomycin, 15; neomycin, 30; carbenicillin, 100. Acid production from carbohydrates was tested as described by Leifson (1963). The utilization of various substrates for growth was determined as described by Baumann \& Baumann (1981), using supplementation with $2 \%(\mathrm{v} / \mathrm{v})$ Hutner's mineral salts solution (Cohen-Bazire et al., 1957) and a $1 \%(\mathrm{v} / \mathrm{v})$ vitamin solution (Staley, 1968), and by Yurkov et al. (1994). Enzyme activities were determined by using the API ZYM system (bioMérieux).

Cell biomass for DNA extraction and for isoprenoid quinone analysis was obtained from cultivation in $\mathrm{MB}$ at $37^{\circ} \mathrm{C}$. Chromosomal DNA was isolated and purified according to the method described by Yoon et al. (1996), except that RNase T1 was used in combination with RNase A to minimize contamination of the RNA. The 16S rRNA gene was amplified by using a PCR with two universal primers, as described previously (Yoon et al., 1998). Sequencing of the amplified $16 \mathrm{~S}$ rRNA gene and phylogenetic analysis were performed as described by Yoon $e t$ al. (2003). Isoprenoid quinones were analysed as described by Komagata \& Suzuki (1987), using reversed-phase HPLC. For cellular fatty acid analysis, cell mass of strain ISL-52 ${ }^{\mathrm{T}}$ was harvested from MA plates after cultivation for 3 days at $37{ }^{\circ} \mathrm{C}$. The fatty acids were extracted and fatty acid methyl esters were prepared according to the standard protocol of the MIDI/Hewlett Packard Microbial Identification System (Sasser, 1990). The DNA G+C content was determined by using the method of Tamaoka \& Komagata (1984), with the modification that the DNA was hydrolysed using nuclease P1 (Sigma) and the resultant nucleotides were analysed by reversed-phase HPLC.

Morphological, cultural, physiological and biochemical characteristics of strain ISL- $52^{\mathrm{T}}$ are given in the species description (see later) and in Table 1. The almost-complete $16 \mathrm{~S}$ rRNA gene sequence of strain ISL- $52^{\mathrm{T}}$ determined in this study comprised $1497 \mathrm{nt}$, representing approximately $96 \%$ of the Escherichia coli $16 \mathrm{~S}$ rRNA gene sequence. A comparative 16S rRNA gene sequence analysis revealed that strain ISL- $52^{\mathrm{T}}$ was phylogenetically most closely affiliated to members of the genus Idiomarina. In the phylogenetic tree based on the neighbour-joining algorithm, strain ISL- $52^{\mathrm{T}}$ joined I. homiensis $\mathrm{PO}-\mathrm{M} 2^{\mathrm{T}}$ at a bootstrap confidence level of $100 \%$ (Fig. 1). The same tree topology was also found in trees based on the maximumlikelihood and maximum-parsimony algorithms. Strain ISL-52 ${ }^{\mathrm{T}}$ exhibited $16 \mathrm{~S}$ rRNA gene sequence similarities of $96.7 \%$ and $94.9-95.8 \%$, respectively, with I. homiensis $\mathrm{PO}-\mathrm{M} 2^{\mathrm{T}}$ and the type strains of other Idiomarina species. The sequence similarities with respect to other species used in the phylogenetic analysis were less than $90.7 \%$.

The predominant isoprenoid quinone detected in strain ISL$52^{\mathrm{T}}$ was Q-8 (at a peak area ratio of approximately $89 \%$ ), as for other Idiomarina species. The fatty acid profile of strain ISL- $52^{\mathrm{T}}$ consisted of the following (each constituting
$>0.5 \%$ of total fatty acids): branched fatty acids iso- $\mathrm{C}_{15: 0}$ $(34.1 \%)$, iso- $\mathrm{C}_{17: 0}(19.9 \%)$, iso- $\mathrm{C}_{17: 1} \omega 9 c(11.8 \%)$, iso$\mathrm{C}_{11: 0}(4.2 \%)$, iso- $\mathrm{C}_{15: 1}(3.9 \%)$, iso- $\mathrm{C}_{13: 0}(1.6 \%)$, iso- $\mathrm{C}_{16: 0}$ $(1.3 \%)$ and anteiso- $\mathrm{C}_{17: 0}(0.5 \%)$; hydroxyl fatty acids iso$\mathrm{C}_{13: 0} 3-\mathrm{OH}(5.0 \%)$ and iso- $\mathrm{C}_{11: 0} 3-\mathrm{OH}(5.0 \%)$; straightchain fatty acids $\mathrm{C}_{16: 0}(4.3 \%)$ and $\mathrm{C}_{18: 0}(0.8 \%)$; cyclo fatty acids cyclo- $\mathrm{C}_{17: 0}(1.7 \%)$ and cyclo- $\mathrm{C}_{19: 0} \omega 8 \mathrm{c}(0.6 \%)$; unsaturated fatty acid $\mathrm{C}_{18: 1} \omega 7 c(0.9 \%)$. This fatty acid profile was similar to those of Idiomarina species, although there are differences in the proportions of some fatty acids, perhaps because of differences in cultivation conditions and extraction procedures (Kwon et al., 2006). The DNA G+C content of strain ISL- $52^{\mathrm{T}}$ was $53.9 \mathrm{~mol} \%$. There were no distinct phenotypic, particularly chemotaxonomic, properties to differentiate strain ISL-52 ${ }^{\mathrm{T}}$ from the genus Idiomarina. Accordingly, it seems reasonable to allocate strain ISL-52 ${ }^{\mathrm{T}}$ to the genus Idiomarina. Strain ISL-52 ${ }^{\mathrm{T}}$ differs from eight recognized Idiomarina species in several phenotypic characteristics, as shown in Table 1. The phylogenetic distinctiveness and differential phenotypic properties are sufficient to allocate strain ISL- $52^{\mathrm{T}}$ to a species that is separate from the recognized Idiomarina species (Stackebrandt \& Goebel, 1994; Table 1). Therefore, on the basis of the data presented, strain ISL- $52^{\mathrm{T}}$ represents a novel species of the genus Idiomarina, for which the name Idiomarina salinarum sp. nov. is proposed.

\section{Description of Idiomarina salinarum sp. nov.}

Idiomarina salinarum (sa.li.na'rum. L. gen. pl. n. salinarum of salt-works).

Cells are Gram-negative and rod-shaped $(0.3-0.6 \times 0.8-$ $3.5 \mu \mathrm{m})$. Colonies on MA are circular to slightly irregular, raised, smooth, glistening, pale yellow in colour and 1.5$2.0 \mathrm{~mm}$ in diameter after 3 days incubation at $37^{\circ} \mathrm{C}$. Growth occurs at 4 and $42{ }^{\circ} \mathrm{C}$, but not at $43{ }^{\circ} \mathrm{C}$. The optimal $\mathrm{pH}$ for growth is between 7.0 and 8.0; growth occurs at $\mathrm{pH}$ 6.0, but not at $\mathrm{pH}$ 5.5. Growth occurs in the presence of $14 \%(\mathrm{w} / \mathrm{v}) \mathrm{NaCl}$, but not in the absence of $\mathrm{NaCl}$ or in the presence of more than $15 \%(\mathrm{w} / \mathrm{v}) \mathrm{NaCl}$. Anaerobic growth does not occur on MA or on MA supplemented with nitrate. Tweens 20, 40 and 60 are hydrolysed, but hypoxanthine, xanthine and urea are not. D-Glucose, D-fructose, Dgalactose, D-cellobiose, D-mannose, trehalose, D-xylose, sucrose, benzoate, L-malate, pyruvate, salicin, formate and L-glutamate are not utilized. Acid is not produced from the following substrates: L-arabinose, D-cellobiose, D-fructose, D-galactose, D-glucose, lactose, maltose, D-mannose, Dmelezitose, melibiose, D-raffinose, L-rhamnose, D-ribose, sucrose, trehalose, D-xylose, D-sorbitol, D-mannitol and myo-inositol. Susceptible to chloramphenicol and polymyxin B and weakly susceptible to gentamicin; resistant to cephalothin, lincomycin, neomycin, novobiocin, oleandomycin, penicillin $G$ and tetracycline. The predominant ubiquinone is Q- 8 . The major fatty acids $(>10 \%$ of total fatty acids) are iso- $\mathrm{C}_{15: 0}$, iso- $\mathrm{C}_{17: 0}$ and iso- $\mathrm{C}_{17: 1} \omega 9 \mathrm{c}$. The DNA G $+\mathrm{C}$ content is $53.9 \mathrm{~mol} \%$ (determined by HPLC). Other phenotypic characteristics are given in Table 1. 
Table 1. Differential phenotypic characteristics of strain ISL $-52^{\top}$ and Idiomarina species

Taxa: 1, strain ISL-52 ${ }^{\mathrm{T}}$; 2, I. abyssalis; 3, I. zobellii; 4, I. baltica; 5, I. loihiensis; 6, I. fontislapidosi; 7, I. ramblicola; 8, I. seosinensis; 9, I. homiensis. Data are from Ivanova et al. (2000), Brettar et al. (2003), Martínez-Cánovas et al. (2004), Choi \& Cho (2005) and Kwon et al. (2006). All are strictly aerobic, motile (by means of single polar or subpolar flagella) and positive for the following: oxidase, catalase and DNase (not determined for $I$. baltica), alkaline phosphatase, esterase (C4), esterase lipase (C8) and leucine arylamidase. All are negative for the following: Gram-stain, starch hydrolysis, lipase (C14), $\alpha$-galactosidase, $\beta$-galactosidase, $\beta$-glucuronidase, $\alpha$-glucosidase, $\beta$-glucosidase, $N$-acetyl- $\beta$-glucosaminidase and $\alpha$ fucosidase. + , Positive reaction; -, negative reaction; $w$, weakly positive reaction; ND, not determined. Data in parentheses are for the type strain.

\begin{tabular}{|c|c|c|c|c|c|c|c|c|c|}
\hline Characteristic & 1 & 2 & 3 & 4 & 5 & 6 & 7 & 8 & 9 \\
\hline Cell morphology & $\begin{array}{l}\text { Straight } \\
\text { or curved } \\
\text { rods }\end{array}$ & Rods & Rods & $\begin{array}{c}\text { Curved } \\
\text { rods }\end{array}$ & $\begin{array}{l}\text { Straight to } \\
\text { slightly } \\
\text { curved rods }\end{array}$ & $\begin{array}{c}\text { Slightly } \\
\text { curved } \\
\text { rods }\end{array}$ & $\begin{array}{c}\text { Slightly } \\
\text { curved } \\
\text { rods }\end{array}$ & $\begin{array}{c}\text { Straight or } \\
\text { slightly } \\
\text { curved rods }\end{array}$ & $\begin{array}{c}\text { Straight or } \\
\text { slightly } \\
\text { s curved rods }\end{array}$ \\
\hline \multirow[t]{2}{*}{ Cell size $(\mu \mathrm{m})$} & $0.3-0.6$ & $0.7-0.9$ & $0.7-0.9$ & $0.4-0.7$ & $0.35-0.45$ & $0.75 \times 3-4$ & $0.75 \times 2-3$ & $0.3-0.6$ & $0.4-0.6$ \\
\hline & $\times 0.8-3.5$ & $\times 1.0-1.8$ & $\times 1.0-1.8$ & $\times 0.7-1.6$ & $\times 0.7-1.8$ & & & $\times 1.0-1.9$ & $\times 0.7-2.0$ \\
\hline $\begin{array}{l}\text { Maximum } \mathrm{NaCl} \text { concn } \\
(\%, w / v) \text { for growth }\end{array}$ & 14 & 15 & 10 & 10 & 20 & 25 & 15 & $20^{*}$ & $1-15$ \\
\hline $\begin{array}{l}\text { Optimal } \mathrm{NaCl} \text { concn } \\
(\%, \mathrm{w} / \mathrm{v})\end{array}$ & $2-3$ & $3-6$ & $3-6$ & $3-6$ & $7.5-10$ & $3-5$ & $3-5$ & $7-10^{*}$ & $3-5$ \\
\hline $\begin{array}{l}\text { Temperature range for } \\
\text { growth }\left({ }^{\circ} \mathrm{C}\right)\end{array}$ & $4-42$ & $4-30$ & $4-30$ & $10-46$ & $4-46$ & $4-45$ & $15-40$ & $4-40$ & $4-45$ \\
\hline $\begin{array}{l}\text { Optimal temperature for } \\
\text { growth }\left({ }^{\circ} \mathrm{C}\right)\end{array}$ & $30-37$ & $20-22$ & $20-22$ & $30-40$ & ND & 32 & 32 & $30-35$ & $25-30$ \\
\hline \multicolumn{10}{|l|}{ Hydrolysis of: } \\
\hline Aesculin & - & - & - & $(+)$ & - & + & + & + & + \\
\hline Casein & - & ND & ND & $\mathrm{ND}$ & $\mathrm{ND}$ & + & + & $\mathrm{ND}$ & - \\
\hline Tyrosine & + & + & + & ND & $\mathrm{ND}$ & - & - & ND & + \\
\hline Gelatin & - & + & + & + & + & + & + & + & + \\
\hline Tween 80 & + & - & - & + & + & + & + & + & + \\
\hline \multicolumn{10}{|l|}{ Growth on: } \\
\hline L-Arabinose & - & - & - & + & - & - & - & - & - \\
\hline Maltose & - & - & - & - & + & - & - & - & - \\
\hline Acetate & - & + & - & + & + & - & - & - & - \\
\hline Citrate & - & - & - & - & + & - & - & - & - \\
\hline Succinate & - & + & + & - & - & - & - & + & - \\
\hline Cystine arylamidase & - & - & - & + & $\mathrm{W}$ & ND & ND & - & + \\
\hline Trypsin & + & - & - & - & + & $\mathrm{ND}$ & $\mathrm{ND}$ & - & + \\
\hline$\alpha$-Chymotrypsin & + & - & $\mathrm{W}$ & + & $\mathrm{W}$ & ND & ND & - & + \\
\hline Acid phosphatase & - & + & + & + & + & $\mathrm{ND}$ & $\mathrm{ND}$ & + & + \\
\hline $\begin{array}{l}\text { Naphthol-AS-BI- } \\
\text { phosphohydrolase }\end{array}$ & - & + & $\mathrm{W}$ & + & + & ND & ND & - & + \\
\hline$\alpha$-Mannosidase & + & - & - & - & - & $\mathrm{ND}$ & $\mathrm{ND}$ & - & - \\
\hline $\begin{array}{l}\text { DNA G }+C \text { content } \\
(\mathrm{mol} \%)\end{array}$ & 53.9 & 50.4 & 48 & $49.4-49.9$ & 47.4 & 46.0 & 48.7 & 45.0 & 45.1 \\
\hline Habitat & $\begin{array}{c}\text { Marine } \\
\text { solar } \\
\text { saltern }\end{array}$ & $\begin{array}{c}\text { Deep sea } \\
\text { (NW } \\
\text { Pacific } \\
\text { Ocean) }\end{array}$ & $\begin{array}{c}\text { Deep sea } \\
\text { (NW } \\
\text { Pacific } \\
\text { Ocean) }\end{array}$ & $\begin{array}{l}\text { Surface } \\
\text { seawater } \\
\text { (central } \\
\text { Baltic Sea) }\end{array}$ & $\begin{array}{c}\text { Hydrotherm- } \\
\text { al vent } \\
\text { (Hawaii) }\end{array}$ & $\begin{array}{l}\text { Saline } \\
\text { wetland } \\
\text { soil } \\
\text { (Spain) }\end{array}$ & $\begin{array}{c}\text { Saline rambla } \\
\text { water } \\
\text { (Spain) }\end{array}$ & $\begin{array}{c}\text { Hypersaline } \\
\text { water of } \\
\text { solar saltern } \\
\text { (Korea) }\end{array}$ & $\begin{array}{l}\text { Seashore sand } \\
\quad \text { Korea) }\end{array}$ \\
\hline
\end{tabular}

${ }^{\star}$ Sea-salt concentration. 


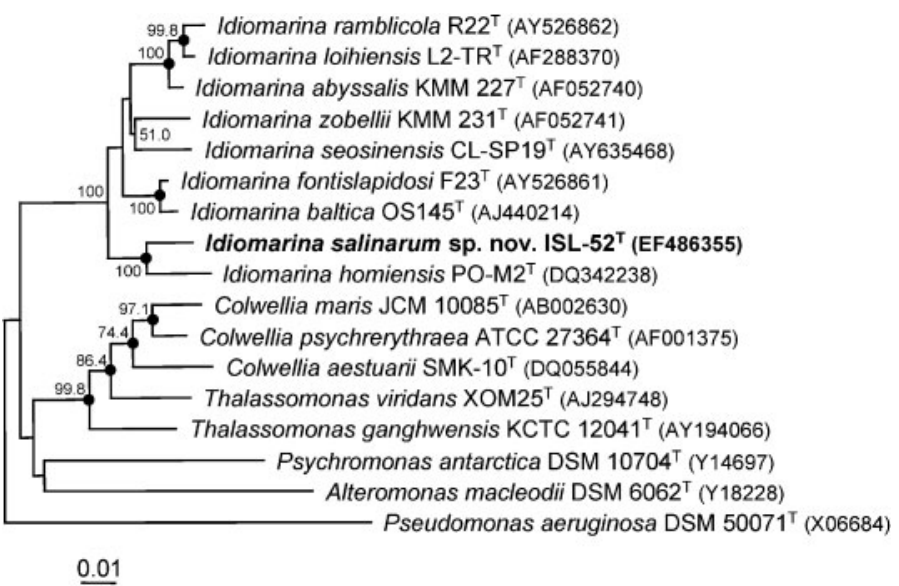

Fig. 1. Neighbour-joining phylogenetic tree, based on 16S rRNA gene sequences, showing the positions of strain ISL- $52^{\top}$, Idiomarina species and some other related taxa. Bootstrap percentages (based on 1000 replications) $>50 \%$ are shown at branch points. Filled circles indicate that the corresponding nodes were also recovered in trees generated with the maximum-likelihood and maximumparsimony algorithms. Pseudomonas aeruginosa DSM $50071^{\top}$ (GenBank accession no. X06684) was used as an outgroup. Bar, 0.01 substitutions per nucleotide position.
The type strain, ISL-52 $2^{\mathrm{T}} \quad\left(=\right.$ KCTC $\quad 12971^{\mathrm{T}}=$ CCUG $54359^{\mathrm{T}}$ ), was isolated from a marine solar saltern of the Yellow Sea, Korea.

\section{Acknowledgements}

This work was supported by the 21C Frontier Program of Microbial Genomics and Applications (grant MG05-0401-2-0) and the Support and Application Project of Biological Resources (grant M10508050004-06N0805-00410) from the Ministry of Science and Technology (MOST) of the Republic of Korea, and by a grant from the KRIBB Research Initiative Program.

\section{References}

Baumann, P. \& Baumann, L. (1981). The marine Gram-negative eubacteria: genera Photobacterium, Beneckea, Alteromonas, Pseudomonas, and Alcaligenes. In The Prokaryotes, pp. 1302-1331. Edited by M. P. Starr, H. Stolp, H. G. Trüper, A. Balows \& H. G. Schlegel. Berlin: Springer-Verlag.

Brettar, I., Christen, R. \& Höfle, M. G. (2003). Idiomarina baltica sp. nov., a marine bacterium with a high optimum growth temperature isolated from surface water of the central Baltic Sea. Int J Syst Evol Microbiol 53, 407-413.

Bruns, A., Rohde, M. \& Berthe-Corti, L. (2001). Muricauda ruestringensis gen. nov., sp. nov., a facultatively anaerobic, appendaged bacterium from German North Sea intertidal sediment. Int $J$ Syst Evol Microbiol 51, 1997-2006.

Choi, D. H. \& Cho, B. C. (2005). Idiomarina seosinensis sp. nov., isolated from hypersaline water of a solar saltern in Korea. Int J Syst Evol Microbiol 55, 379-383.

Cohen-Bazire, G., Sistrom, W. R. \& Stanier, R. Y. (1957). Kinetic studies of pigment synthesis by nonsulfur purple bacteria. J Cell Comp Physiol 49, 25-68.

Cowan, S. T. \& Steel, K. J. (1965). Manual for the Identification of Medical Bacteria. London: Cambridge University Press.

Donachie, S. P., Hou, S., Gregory, T. S., Malahoff, A. \& Alam, M. (2003). Idiomarina loihiensis sp. nov., a halophilic $\gamma$-Proteobacterium from the Lō'ihi submarine volcano, Hawai'i. Int J Syst Evol Microbiol 53, 1873-1879.

Ivanova, E. P., Romanenko, L. A., Chun, J., Matte, M. H., Matte, G. R., Mikhailov, V. V., Svetashev, V. I., Huq, A., Maugel, T. \& Colwell, R. R. (2000). Idiomarina gen. nov., comprising novel indigenous deep-sea bacteria from the Pacific Ocean, including descriptions of two species, Idiomarina abyssalis sp. nov. and Idiomarina zobellii sp. nov. Int J Syst Evol Microbiol 50, 901-907.

Komagata, K. \& Suzuki, K. (1987). Lipid and cell-wall analysis in bacterial systematics. Methods Microbiol 19, 161-207.

Kwon, S.-W., Kim, B.-Y., Weon, H.-Y., Baek, Y.-K., Koo, B.-S. \& Go, S.-J. (2006). Idiomarina homiensis sp. nov., isolated from seashore sand in Korea. Int J Syst Evol Microbiol 56, 2229-2233.

Lanyi, B. (1987). Classical and rapid identification methods for medically important bacteria. Methods Microbiol 19, 1-67.

Leifson, E. (1963). Determination of carbohydrate metabolism of marine bacteria. J Bacteriol 85, 1183-1184.

Martínez-Cánovas, M. J., Béjar, V., Martínez-Checa, F., Páez, R. \& Quesada, E. (2004). Idiomarina fontislapidosi sp. nov. and Idiomarina ramblicola sp. nov., isolated from inland hypersaline habitats in Spain. Int J Syst Evol Microbiol 54, 1793-1797.

Sasser, M. (1990). Identification of bacteria by gas chromatography of cellular fatty acids, MIDI Technical Note 101. Newark, DE: MIDI.

Stackebrandt, E. \& Goebel, B. M. (1994). Taxonomic note: a place for DNA-DNA reassociation and $16 \mathrm{~S}$ rRNA sequence analysis in the present species definition in bacteriology. Int J Syst Bacteriol 44, 846-849.

Staley, J. T. (1968). Prosthecomicrobium and Ancalomicrobium: new prosthecate freshwater bacteria. J Bacteriol 95, 1921-1942.

Tamaoka, J. \& Komagata, K. (1984). Determination of DNA base composition by reversed-phase high-performance liquid chromatography. FEMS Microbiol Lett 25, 125-128.

Yoon, J.-H., Kim, H., Kim, S.-B., Kim, H.-J., Kim, W. Y., Lee, S. T., Goodfellow, M. \& Park, Y.-H. (1996). Identification of Saccharomonospora strains by the use of genomic DNA fragments and rRNA gene probes. Int J Syst Bacteriol 46, 502-505.

Yoon, J.-H., Lee, S. T. \& Park, Y.-H. (1998). Inter- and intraspecific phylogenetic analysis of the genus Nocardioides and related taxa based on 16S rDNA sequences. Int J Syst Bacteriol 48, 187-194.

Yoon, J.-H., Kim, I.-G., Shin, D.-Y., Kang, K. H. \& Park, Y.-H. (2003). Microbulbifer salipaludis sp. nov., a moderate halophile isolated from a Korean salt marsh. Int J Syst Evol Microbiol 53, 53-57.

Yurkov, V., Stackebrandt, E., Holmes, A., Fuerst, J. A., Hugenholtz, P., Golecki, J., Gad'on, N., Gorlenko, V. M., Kompantseva, E. I. \& Drews, G. (1994). Phylogenetic positions of novel aerobic, bacteriochlorophyll a-containing bacteria and description of Roseococcus thiosulfatophilus gen. nov., sp. nov., Erythromicrobium ramosum gen. nov., sp. nov., and Erythrobacter litoralis sp. nov. Int J Syst Bacteriol 44, 427-434. 